Yuliya G. Myslyakova Ural State University of Economics, Institute of Economics (Ural branch of RAS), Ekaterinburg, Russia

Elena A. Shamova Institute of Economics (Ural branch of RAS), Ekaterinburg, Russia

\title{
Export-oriented industrial technologies as drivers of regional economic growth
}

\begin{abstract}
The article searches for sources to boost regional economic growth, which is highly significant for building an effective industrial policy for the development of the state. The research proves a scientific hypothesis that in modern economic conditions export-oriented industrial technologies act as drivers of the regional economic growth. The methodological basis of the study rests on a set of theories of economic growth and regional economics. The results of the analysis of the "activating", "integrating" and "institutional" approaches allowed the authors to revise the concept "driver of economic growth" and propose a classification of the drivers, which was based on the criteria of the sphere of origin; source; method of origin; genesis and level of economic growth. The article identifies priority types of drivers that arise from the development of export activity in the territory. Their impact on economic growth was analysed through econometric modelling. Proceeding from the data on the subjects of the Russian Federation for 2011-2016, the paper unveils empirical scientific evidence that export-oriented industrial technologies generate two most influential impulses for economic growth: growth in the volume of shipments and in tax revenues coming to regions' consolidated budgets. The authors established that for the observed period, Russian industrial exports were not based on innovation. The practical significance of the study lies in the possibility of applying its findings for devising socioeconomic development strategies of regions of the Russian Federation.
\end{abstract}

Keywords: region; economic growth; driver of economic growth; export; export-oriented technologies.

For citation: Myslyakova Yu. G., Shamova E. A. Export-oriented industrial technologies as drivers of regional economic growth. Journal of New Economy, 2019, vol. 20, no. 2, pp. 166-179. DOI: $10.29141 / 2073-1019-2019-20-2-10$

Received January 21, 2019.

\section{Introduction}

The problem of analysing and forecasting economic growth has been relevant for the past fifty 1 years. This topic is in high demand in economic research, since its findings are important for building effective policies of economic development in the countries. Despite the long-term study of this topic, economic growth is not fully explored. Consideration of factors of economic growth usually helps identify not only the most common of them that are typical of many economies in the world, but also those that are typical of a certain group of countries or a certain stage in the development of their economic systems. Among other things, the process of economic growth is often studied by only looking into one of many drivers behind the long-term growth of real GDP. These basically include the efficient use of resource base, technological development, development of human capital, innovation without reference to the external economic situation, which is unacceptable in the modern economic conditions when globalisation, as well as the 
opposite trends towards regionalisation of economic relations, rise of protectionism, sanctions and counter-sanctions, significantly affect economic performance.

The objective of this study is to demonstrate that export-oriented industrial technologies are one of the modern drivers of regional economic growth. To achieve this, a number of theoretical and methodological tasks need to be addressed:

- to identify and systematise approaches towards understanding the content of the definition of the "driver of economic growth";

- to convey the authors' understanding of the basic definition and suggest its classification;

- to present a framework for the study of the positive impact of export-oriented industrial technologies on GRP;

- to evaluate the growth impulses generated by export-oriented industrial technologies.

The solution of these problems will increase the scientific and practical importance of recognising the international relations of a region, as well as the export activities of industrial enterprises in terms of their influence on the socio-economic development of the area.

\section{Theoretical approaches towards understanding drivers of economic growth}

By now several approaches to understanding the essence of a driver of economic growth can be singled out.

The first approach is an "activating" one, where a driver is associated with a source activating the poles of economic growth that were first introduced as a scientific concept by Myrdal [1955]. His main idea was that developed regions, as opposed to stagnating ones, have their own growing potential for self-development. This is due to a cumulative effect of favourable conditions stimulating interaction with successful industries of other industrial complexes. As a result, there is a co-evolutionary development of all participants involved in the production process, which leads to deeper territorial differences and to various industries clustered within the economically successful regions. In this approach, the driver is a mechanism that artificially activates the creation and development of such growth poles. Perroux [1955], Pottier [1963], Friedman [1975], and Lasuen [1969] believed the leading industries in the region to be the drivers. Therefore, it is necessary to identify those enterprises that can boost the area's socioeconomic development, and to provide them with the state investment support before their internal systems of self-support and self-development are activated. At the same time, this should be done carefully as these drivers can lead to polarisation of the area's development and would only work at the local level rather than nationwide. The drivers may later cease to exert positive influence on sustainable development of the economy and start acting as a brake on economic transformations and as a counter-productive force preventing simultaneous implementation of economic reforms [Orekhova, 2008, p. 21].

Other authors, including Schumpeter [1982], Drucker [2012], Whitfield, Knight [2003], etc., elaborate on the previous point of view and believe that the drivers of economic growth are the industries that positively affect the quality of life of the population and always function on an innovative basis that allows them to win the competition and attract the maximum amount of financial resources. Arrow, Grossman, Solow [2000], and others mark human capital a driver of economic growth. For example, according to Romer [1990], there is a positive correlation between economic growth and the level of human capital concentrated in the field of acquiring new knowledge. Therefore, leading industries should also reproduce new knowledge whose application would increase the GRP and GDP growth rates.

The second approach is an "integrating" one where the driver of economic growth is a management mechanism that captures the impulses from the external environment and converts them into signals for integrative action sent to all participants operating in a given area thus 
changing the directions of economic development and growth both at the meso- and macro level. For example, the team of Russian authors who have long been involved in analysing the problems of ensuring the sustainable development of the Russian economy [Ivanova, Terskaya, 2015; Akhapkin, 2014; Makhortov, 2017; Kostin, 2017] define a driver of economic growth as a set of mechanisms that capture market fluctuations not so much from the inside as from the outside of a country and catalyse and translate the impulses of demand into the powerful flow capable of transforming the country's economic reality with the use of available resources. The integrative approach emphasises that the nature of driver's genesis is not as important as its basic function, i.e. to form an integrated system of vertical and horizontal industrial chains that recognise and spread the impulses within the national economic system. In this fashion, any phenomena that overcome the disintegrative factors of the Russian economy - such as weak intra- and inter-sectoral cooperation, low added value, low solvency of the population, underdeveloped infrastructure and technology, low level of digitalisation can act as drivers. In addition, by the strength of their influence on the quality of life, the authors give priority to industrial complexes.

The third approach is "institutional" where the drivers of economic growth are the mechanisms that shape the country's optimal configuration of conditions for meeting the growing demand by using the state and regional reserves. The ambiguous point here is the fact that optimality of a given configuration is specific to each area's economy and depends on the history of its economic development. For example, Nelson, Winter [1982], David [1985], Hodgson [Hodgson, Knudsen, 2004], Becker [2005] believe that “...where we go next depends not only on where we are now but also on where we were before" [Ivanter, 2014]. Therefore, the drivers of economic growth in this case shall include competition; export; public-private partnership; transport, innovation, financial, information, and communication infrastructure; support for small and medium businesses; cluster networks.

The identified approaches towards understanding the concept of a driver of economic growth allowed the authors to develop their own understanding of this term and its classification. The authors adhere to an integrative approach and further define a driver as an industrial mechanism that generates the interconnected sectoral, innovative, social, and economic impulses of the regional development in response to the signals coming from external markets and supports sustainable growth of GRP. Classification of the drivers of economic growth is presented in Table 1.

Table 1. Classification of economic growth drivers

Таблица 1. Классификация драйверов экономического роста

\begin{tabular}{|l|c|}
\hline Classification criterion & Drivers \\
\hline Driver's sphere of origin & Industrial \\
Agrarian & Financial \\
& Social \\
& Business \\
Driver's source & Competition \\
& Globalisation (international trade) \\
& Public-private partnership \\
& Industry specialisation \\
\hline Driver's method of origin & Production \\
& Innovative \\
& Digital \\
& Cluster (network) \\
& Diffusion \\
\hline
\end{tabular}


Table 1. (Concluded)

Продолжение таблицы 1

\begin{tabular}{|l|c|}
\hline \multicolumn{1}{|c|}{ Classification criterion } & Drivers \\
\hline \multirow{3}{*}{ Genesis } & Sectoral \\
& Spatial \\
& Institutional \\
\multirow{2}{*}{ Level of economic growth } & Micro- \\
& Meso- \\
\hline
\end{tabular}

Based on the above classification of drivers of economic growth, we suggest the following scientific hypothesis: at the present time of growing international trade, export-oriented industrial technologies act as the driver of economic growth of the region. The formulation of this hypothesis reflects the priority typological characteristics of the drivers which will be examined later on in this study.

\section{Methodological rationale behind considering export-oriented industrial technologies as a driver of regional economic growth}

The rationale for treating the export-oriented industrial technologies as a driver of a country's economic growth is laid down in the Decree of the President of the Russian Federation, which specifies the areas of the breakthrough scientific, technological, and socioeconomic development of the Russian Federation. It focuses on the importance of creating a high-performance exportoriented sector that would develop on the basis of modern technologies and be provided with highly qualified personnel in such basic sectors of economy as the manufacturing industry and agro-industrial complex ${ }^{1}$. By 2024, the targeted share of non-resource exports (works, services) in GDP is to amount to $20 \%$; the volume of the non-energy related non-resource exports in monetary terms is planned to reach 250 billion US dollars, of which engineering products are projected to account for 50 billion US dollars and agro-industrial products - for 45 billion US dollars. In actual fact, as of the end of 2017, the situation with the Russian exports can be described as follows. In 2014-2017, the share of fuel in the total exports decreased (from 70 to $60 \%$ ), the share of food products increased (from 2 to $6 \%$ ), the share of machinery and equipment rose (from 5 to $8 \%$ ), while the share of other product groups remained unchanged. For example, the increase in exports of machinery, equipment, and vehicles in 2017 was $15.8 \%$ year over year; exports of mechanical equipment increased by $25.4 \%$; the exports of aircrafts were up by $9.7 \%$, and cars - by $20.7 \%^{2}$. With that in mind, in 2017 five leading importers of Russian industrial goods included China (exports from Russia to this country amounted to 38,918.6 million US dollars); the Netherlands (exports from Russia worth 35,606.7 million US dollars); Germany (exports from Russia worth 25,737.3 million US dollars); Belarus (exports from Russia worth 18,595.0 million US dollars); and Turkey (exports from Russia worth 18,697.8 million US dollars).

The authors analysed the impact of regions' foreign economic relations on their GRP to justify the approach of considering export-oriented industrial technologies as a driver of regional economic growth. The main areas of focus were the exports of goods produced within the territory; imports of goods, and foreign investment. The data presented in Figs. 1-3 shows a correlation between regional exports and their GRP $\left(R^{2}=0.651\right)$.

\footnotetext{
${ }^{1}$ On the national goals and strategic tasks of the development of the Russian Federation for the period up to 2024. Decree of the President of the Russian Federation of May 7, 2018 No. 204 (Section 1, subsection “i”).

2 http://www.ved.gov.ru/monitoring/foreign_trade_statistics/basic_goods_export/ (in Russ.)
} 


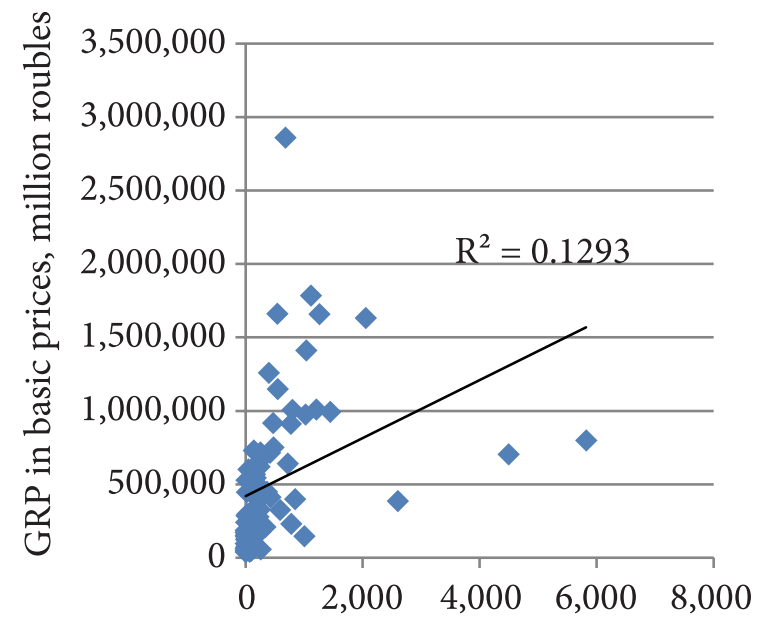

Foreign direct investment, million US dollars

Fig. 1. Impact of foreign direct investment of regions of the Russian Federation on their GRP Рис. 1. Оценка влияния прямых иностранных инвестиций регионов РФ на их ВРП

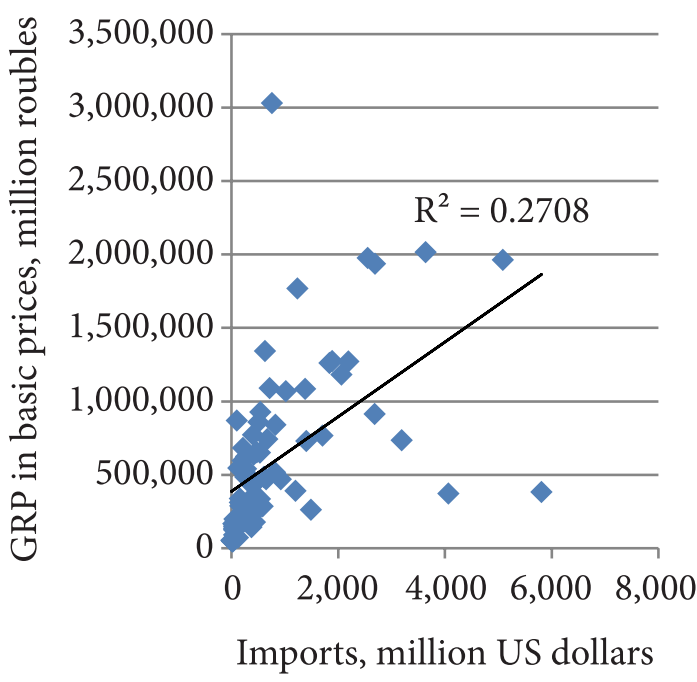

Fig. 2. Impact of regions' imports on their GRP

Рис. 2. Оценка влияния импорта регионов на их ВРП

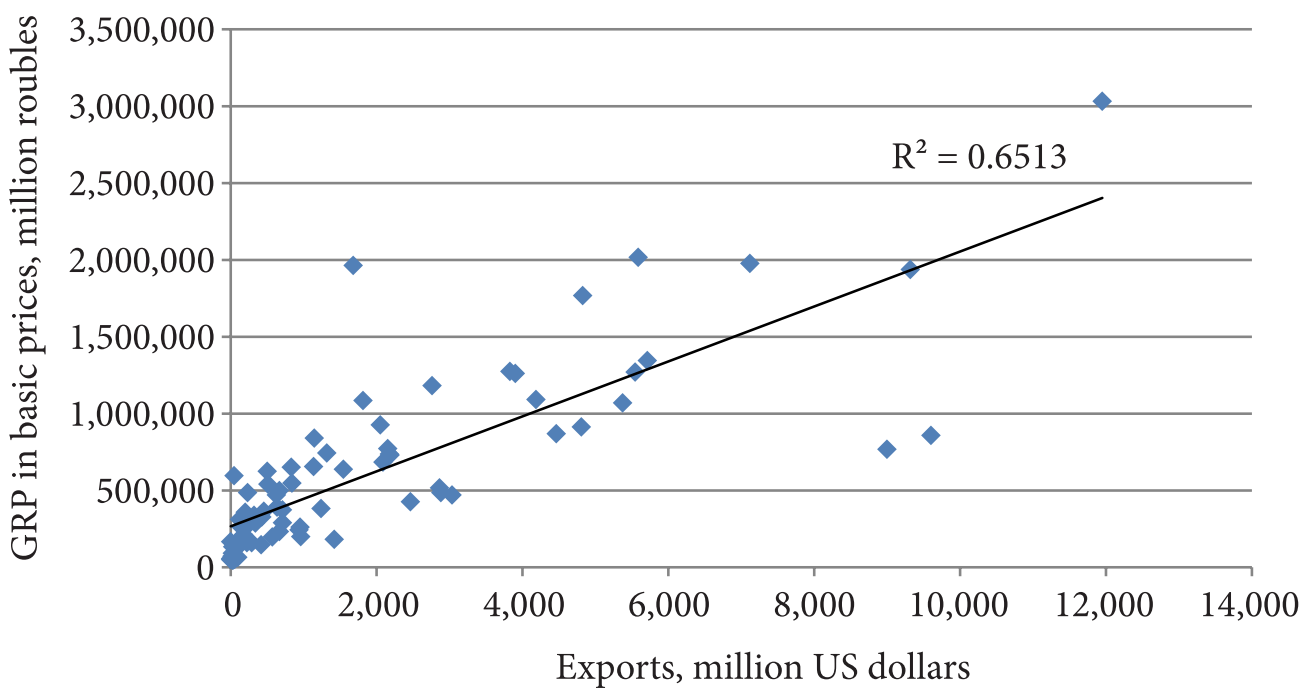

Fig. 3. Impact of exports from regions of the Russian Federation on their GRP Рис. 3. Оценка влияния экспорта регионов РФ на их ВРП

Consequently, export streams formed by industrial production technologies of the basic industries act as a source of regions' economic growth. Let's consider the framework of integral effect that the export-oriented industrial technologies have on economic growth of a region, represented as generation of various impulses that stimulate and support the growth of GRP (Fig. 4).

Thus, export-oriented industrial technologies trigger primary impulses for economic development. First of all, there is an increase in the production and sales of goods, since the export orientation of manufacturing allows enterprises to operate both on the national and international markets. An increase in the volume of production will lead to a higher demand for industrial goods; rise in employment and potential increase in jobs. A higher income of industrial enterprises will increase tax revenues. Since the industrial complex is usually the main participant in the innovation processes, the increase in production will be accompanied with modernisation and innovative transformations. 


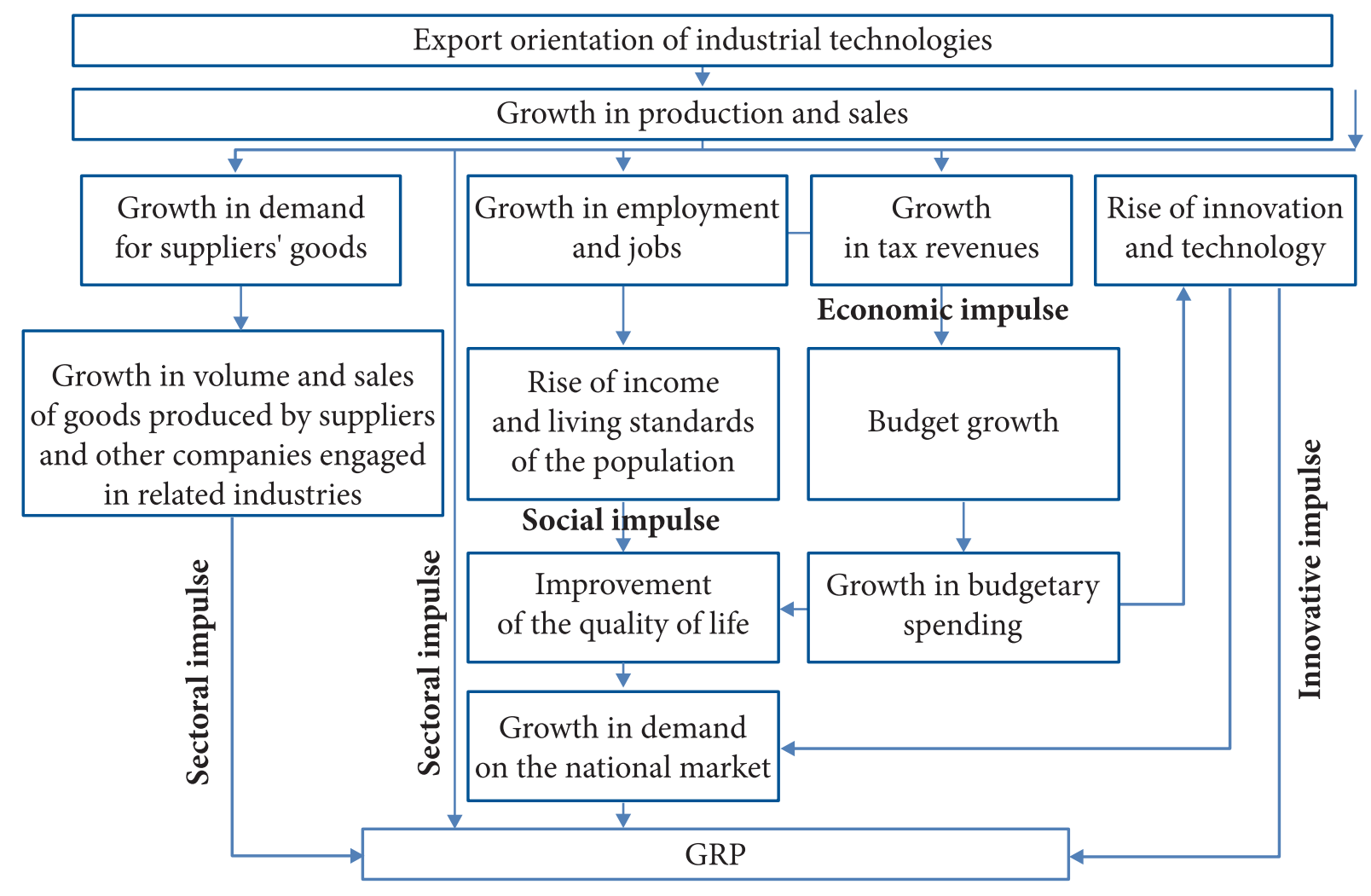

Fig. 4. Framework of the impact of export-oriented industrial technologies on the regional economic growth

Рис. 4. Концептуальная схема влияния экспортоориентированных промышленных технологий на экономический рост региона

The existing industrial technologies will undergo changes and become more sophisticated but bringing the economies of scale from the expansion of foreign trade on international markets. It turns out that primary impulses (sectoral, economic, innovative, and social) will be generated independently and spread in waves as the sources of support for sustainable growth of GRP. Therefore, to prove the authors' hypothesis, the ability of export-oriented industrial technologies to generate primary growth impulses for the GRP growth should be tested in practice.

\section{Assessing the impact of export-oriented industrial technologies on the regional economic growth}

When developing a methodology for evaluating certain factors that influence economic growth, it is necessary to bear in mind the sub-territorial processes taking place within the country due to significant regional differentiation of Russia. There are several methodological approaches applied by various researchers to solve similar tasks.

The first approach employs econometric analysis and mathematical model-building to assess the degree of influence of a particular factor on GRP dynamics. This methodological apparatus undoubtedly makes it possible to identify certain interactions, but calculations in the studies are often performed for the sake of calculations themselves, which leads to criticism in modern scientific discussion. Econometric models should be tied in with the theoretical and methodological basis for studying the observed processes, should serve it and not be a goal in and of itself.

Under the second approach, the regions are often classified by identifying the general and specific features of territorial processes to ensure more accurate management. This approach meets the objectives of state management to a greater extent, but this is also a reason for its 
limitations. When identifying indicators and boundary conditions to determine the type of area and then decide on a certain variant of state influence, it is impossible to reliably define the boundaries separating one type of region from another or to identify sufficient and necessary number of region types without missing specific features of the processes inherent in a particular region.

The third approach uses the methods of analysing large amounts of data. There are quite a few methods that differ in their statistical base and calculation algorithms. For example, the method of data envelopment analysis (DEA) used to determine the performance of production facilities of individual enterprises and regional clusters, requires specialist software (DEA Frontier, MaxDEA, OpenSource DEA and other packages). It can create complex modifications of the basic DEA models to evaluate the performance of large production facilities over time).

In this paper, the method used to assess the impact of export orientation of the industrial complex on the regional economic growth proceeds from the fact that, in the first place, a set of statistical indicators characterising export orientation as a driver of economic growth is made up. The choice of indicators is based on theoretical substantiation of the relationship between the development of export flows and dynamics of socio-economic processes in the area. Only then the degree of impact of individual factors on economic growth can be assessed to identify the correlation between the indicators' dynamics by means of econometric modelling.

The specificity of the authors' approach consists in the fact that the effect of export-oriented industrial technologies on the regional economic growth is evaluated in terms of the influence that export flows of industrial enterprises have on the primary impulses of the area's economic growth. Consequently, econometric calculations cannot be performed until the factors to be included into econometric models are theoretically identified, thus eliminating the problem of discrepancy between the calculated data and theoretically justified economic processes taking place in the territory.

It should be noted that when collecting raw data, the authors faced a major problem with the use of statistical base which was associated with the presence of strong outliers affecting the normal distribution of data. This is due to the fact that such federation subjects as Moscow, Moscow oblast, and St. Petersburg are the administrative and financial centres of the country. Their statistics account for a significant amount of foreign trade turnover even though the production facilities are in fact located outside these territories. Therefore, for the purposes of analysis these regions were excluded from the set of observations that comprise the panel data for all federation subjects for 2011-2016. Thus, due to mismatch between the location of a production facility and a registered office of a legal entity that owns this facility, part of data was excluded from the analysis. However, a large number of observations (459) that made it to the analysis after eliminating the outliers still allow the correlations that reflect the real processes in the regions of the Russian Federation to be considered unbiased.

Figs. 5-8 show the estimates for the primary impulses for economic growth generated by a given driver in a region: growth in production (sectoral impulse); rise of innovation (innovative impulse); growth in regional tax revenues (economic impulse); rise of living standards (social impulse). The remaining impulses shown in Fig. 4 are their derivatives.

The presented estimates allow identifing various strengths of correlations that reflect the generation of primary impulses and predicting with higher or lower probability the expected growth of the resulting indicator, which in our case is the GRP.

The strongest correlation and, consequently, the highest likelihood to impact on the economic growth are demonstrated by an increase in the shipment of domestically-produced goods due to the growth in their exports. The second closest correlation is shown by regional tax revenues due to the rising tax base. The correlation between innovations introduced in the region as 


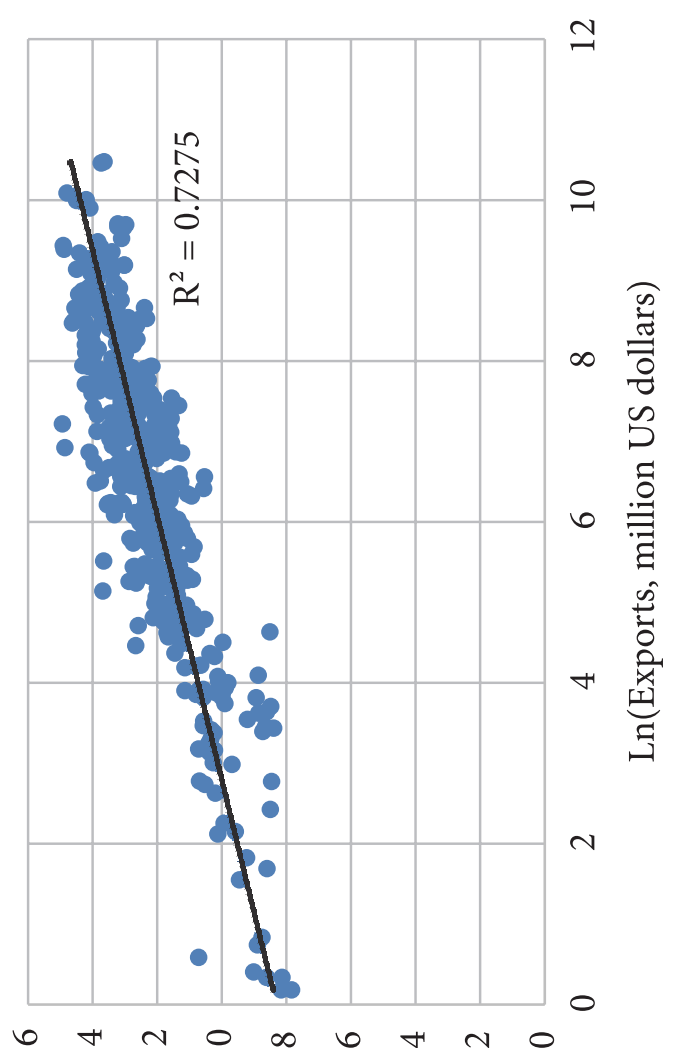

(səannox uo!̣!l!u 'padd!̣ys

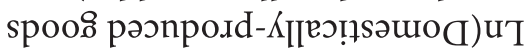

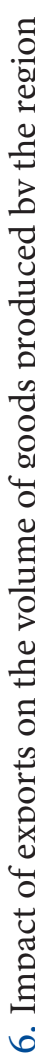

$\infty$

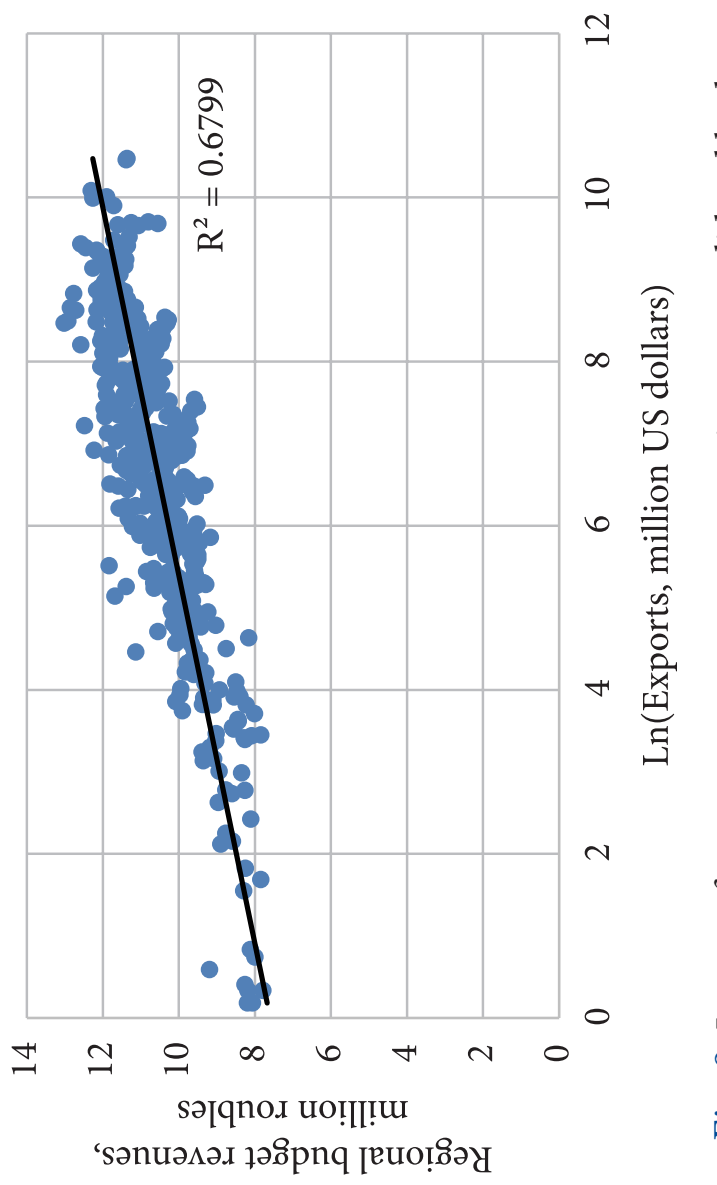

苛

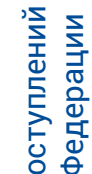

䨔

000 要

击

을

की $\pi$

州

음 춘

य

4.0 .

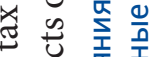

ฐ

के

要

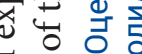

定

蒫

$\infty$ 옹

نำ

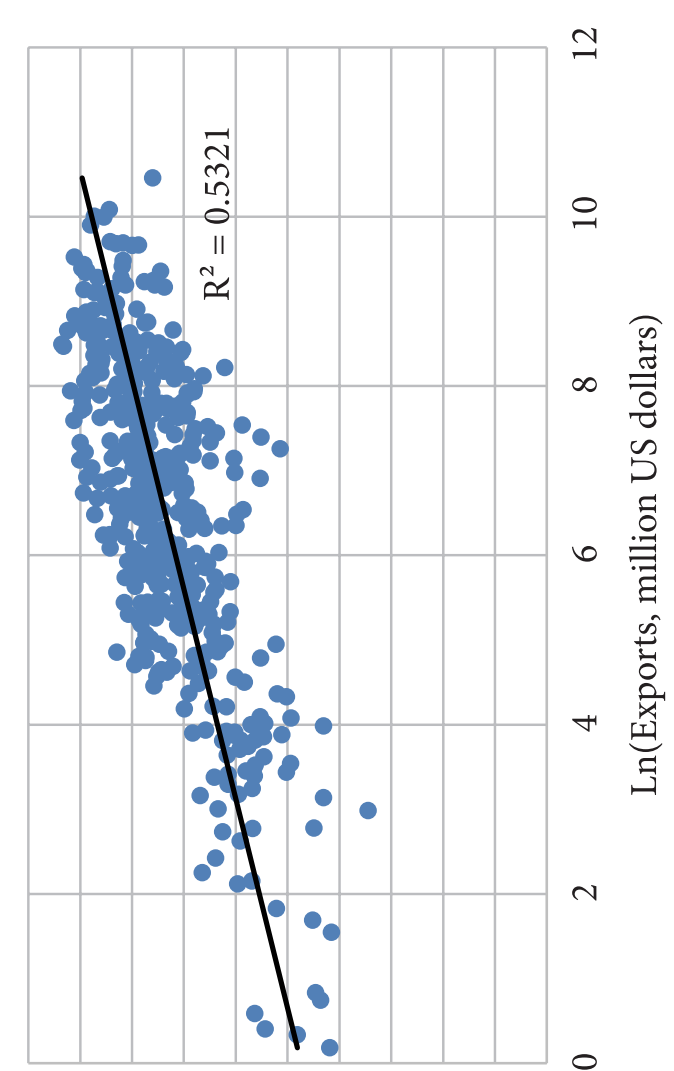

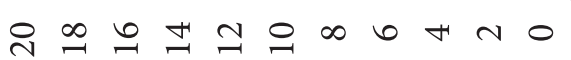

(sərqnox uo!̣!!!u 'uo!̣esouu!

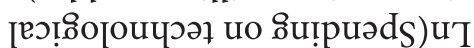

.0.

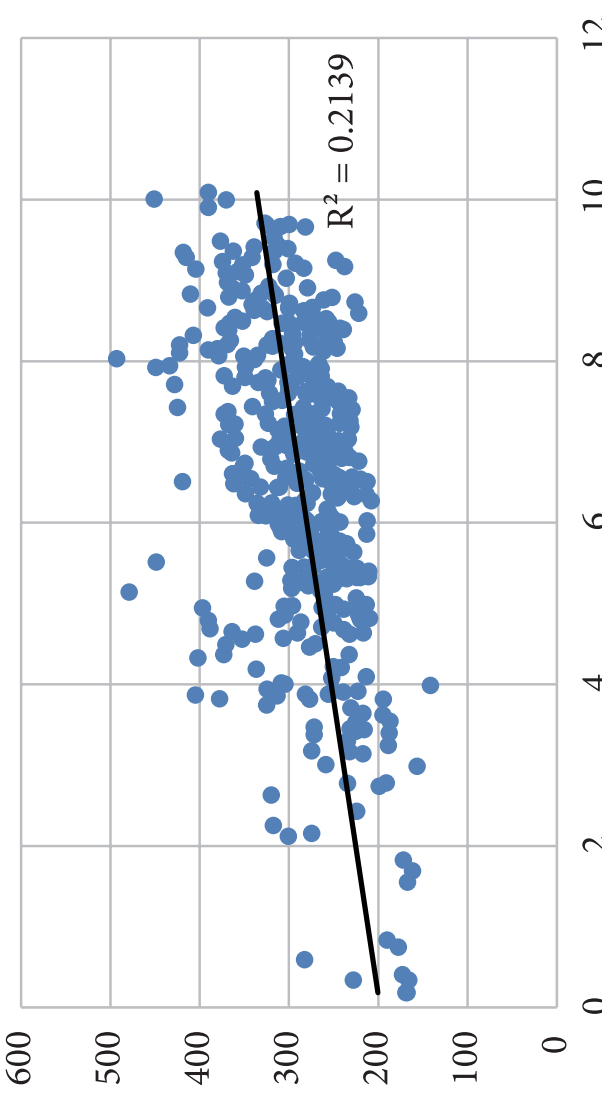

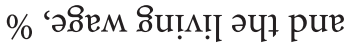

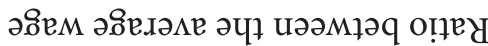

I

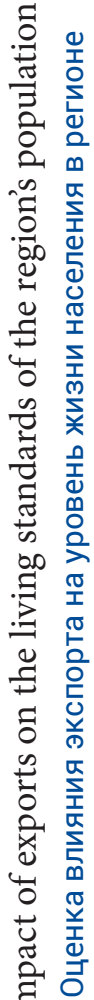
苨 임 둥 فำ 
a result of technology transfer in the process of entering foreign markets and the exports volumes is weaker. This means that implementation of export-promoting policies does not necessarily lead to renovation of production. Although the strength of relationship is rather high, there is no reason to discard this factor at this stage of assessment.

The authors believe that when developing export-stimulating programmes additional measures need to be contemplated that would stimulate innovations and introduction of new, globally competitive technologies.

As for the last impulse, the correlation between the living standards of the region's population and the development of export-oriented industries has not been proven. This is due to the fact that in Russia the country-average number of people employed in the industrial enterprises amounts to $26 \%^{1}$; therefore, wage increase as a result of development of export-oriented production is diluted by a large proportion of workers in non-productive sectors not related to this process and having other impulses for growth.

As a result, three factors were included in the econometric model for assessing the effect of the export-oriented technologies of the region's industrial complex on its economic growth: number of shipments X1, tax revenues coming to consolidated budgets of the region X2, and spending on technological innovation X3. These factors are reviewed in conjunction with exports, which allows concluding what growth impulses exactly will be triggered in the region by the growth of its exports.

The results of modelling the dependence of economic growth rates in the subjects of the Russian Federation are presented in Table 2. As can be seen from the calculated data, the third factor (spending on technological innovation) in the multiple regression model of relationship between the economic growth rates in the subjects of the Russian Federation and the three factors is insignificant. Based on this conclusion, the third factor was excluded from the resulting regression model with only two factors left to test the relationship. This ensured the significance of the coefficient of determination in each model. The resulting regression equations were tested by Fisher's F-test.

Table 2. Main parameters of the resulting regression models (number of observations $=459$ for 2011-2016)

Таблица 2. Основные параметры полученных регрессионных моделей (число наблюдений $=459$ за 2011-2016 гг.)

\begin{tabular}{|c|c|c|c|}
\hline Variable & Coefficient & Std. Error & p-value \\
\hline \multicolumn{4}{|l|}{ Model 1. GRP dependence on three factors (multiple $R=0.986$ ) } \\
\hline Volume of domestically produced goods shipped (factor X1) & 0.401347 & 0.028638 & $2.32 \mathrm{E}-37$ \\
\hline $\begin{array}{l}\text { Amount of tax revenues coming to consolidated budgets of the } \\
\text { subjects of the Russian Federation (factor X2) }\end{array}$ & 7071.6 & 233.8555 & $5 \mathrm{E}-111$ \\
\hline Amount of spending on technological innovation (factor X3) & 4.57553 & 0.539863 & 0.122133 \\
\hline \multicolumn{4}{|l|}{ Model 2. GRP dependence on two factors (multiple $R=0.984$ ) } \\
\hline Volume of domestically produced goods shipped (factor X1) & 0.327943 & 0.029336 & $8.21 \mathrm{E}-26$ \\
\hline $\begin{array}{l}\text { Amount of tax revenues coming to consolidated budgets of the } \\
\text { subjects of the Russian Federation (factor X2) }\end{array}$ & 6742.546 & 247.8381 & $1.29 \mathrm{E}-97$ \\
\hline \multicolumn{4}{|l|}{ Model 3. X1 dependence on exports (multiple $R=0.713$ ) } \\
\hline Exports (factor EXP) & 99620.23 & 4576.627 & $1.2 \mathrm{E}-72$ \\
\hline \multicolumn{4}{|l|}{ Model 4. X2 dependence on exports (multiple $R=0.719$ ) } \\
\hline Exports (factor EXP) & 11.89798 & 0.53664 & $1.58 \mathrm{E}-74$ \\
\hline
\end{tabular}

${ }^{1}$ Russian statistical yearbook. Moscow: Russian Federal State Statistics Service, 2017. 
Therefore, the model of GRP linear regression as a function of growth impulses generated with the development of export-oriented technologies has the following form:

$$
\begin{gathered}
\text { GRP }=0.328 \times \text { SHIPMENT }+6,742.546 \times \text { TAX } \\
\text { SHIPMENT }=99,620.23 \times \text { EXPORT; TAX }=11.9 \times \text { EXPORT }
\end{gathered}
$$

It can be seen from the graph displaying the comparison of simulated data with observed GRP (Fig. 9) that the resulting model matches well with the factual data. The peaks are related to the same subjects of the Russian Federation (industrialised regions) year on year.

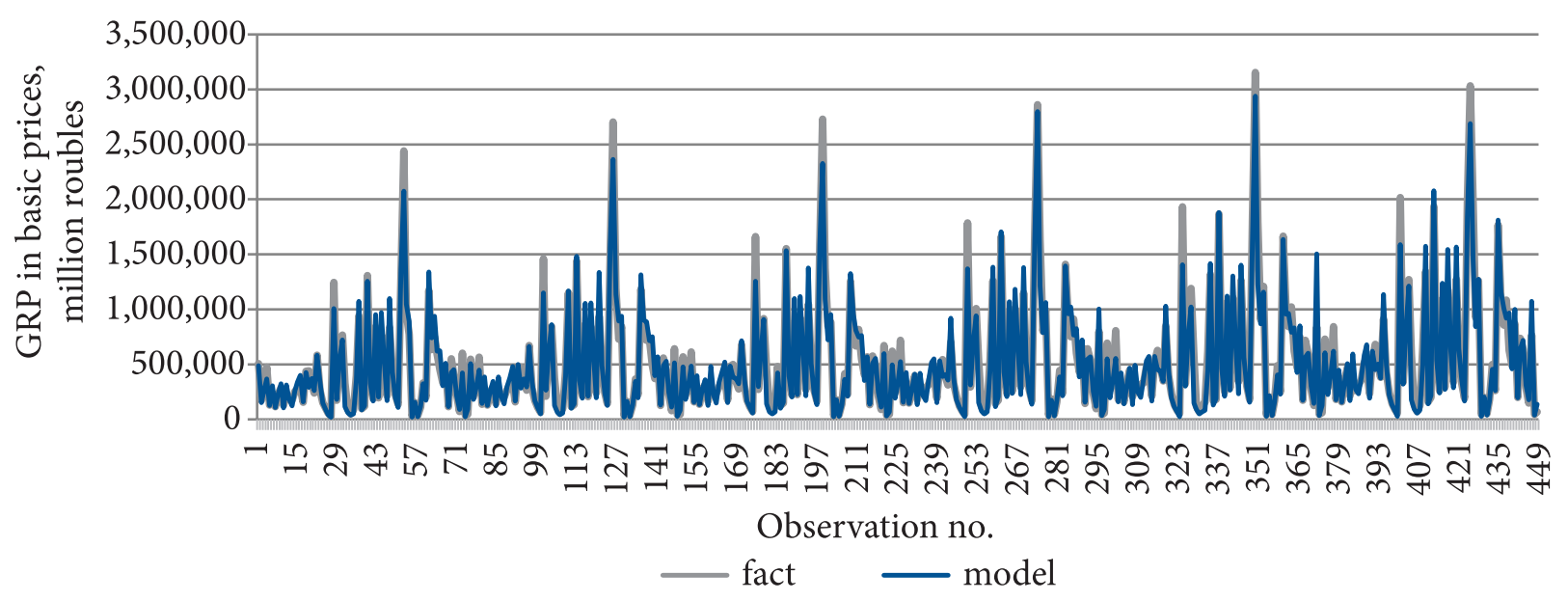

Fig. 9. Comparison of simulated data with observed volumes of gross regional product for 2011-2016

Рис. 9. Сопоставление фактических и смоделированных данных валового регионального продукта за 2011-2016 гг.

Therefore, the increase in region's exports by 1,000 roubles serves as an impulse for the growth in the region's shipments of finished products by 99,620 thousand roubles and for the growth of region's tax base by 11.9 thousand roubles. This gives an impulse for the growth of GRP by $(0.328 \times 99,620.23+6,742.546 \times 11.9)=32,675.4+3.9=32,679.3$ thousand roubles

In general, the comprehensive analysis of the strength of the above relationships allows concluding that the authors' hypothesis that export-oriented industrial technologies are the driver of economic growth in a region, has been proven. The function of these drivers should be continuously supported by:

- strengthening the existing positions of Russian export-oriented companies in global markets,

- involving new regional exporters in the country's foreign economic activity.

In addition, growing enterprises that increase their output when entering new markets should have no infrastructure- and resource-related constraints to their development; therefore, it is important to create the proper environment for economic development at the regional level. Without such environment, including transport, electric power industry, as well as efficient management and minimisation of administrative barriers, any substantial economic growth is out of question.

As for the specific mechanisms that can be used to develop export-oriented industries, the federal programmes and various forms of support need to be supplemented with a number of measures taken at the regional level. A comprehensive analysis of the region's export activities broken down by main product groups needs to be performed in order to determine the position of regional exporters in the global market and identify the conditions necessary to maintain or improve their positions. The quality of such analysis directly depends on cooperation between 
the regional authorities and manufacturing enterprises in order to identify the non-specific features of running and developing a particular business. It is important to make provisions for establishing a regional institution which could provide such information. It is desirable that it works as a permanent business forum. There are currently two institutions that could serve as a basis for an expanded forum. These are the regional chambers of commerce and industry and regional offices of the Russian Export Centre. The role of this forum is even more significant in finding potential foreign markets for regional producers. When new regional exporters get engaged in foreign trade, it is extremely important to put the focus of support on the export activities of small and medium-sized enterprises. Attention should be paid to information support, training of the companies' management, as well as on assistance in certification, adaptation of a product to a new market and making it consistent with the standards and requirements of the consumer country. For the purposes of effective government regulation over the whole variety of factors influencing the development of exports in a particular region, a systematic monitoring needs to be introduced, including both descriptive and causal studies of these factors. The obtained information would make it possible to increase the effectiveness of state support measures by adjusting them according to the results from a comprehensive analysis of their practical implementation.

\section{Conclusion}

The authors performed the set tasks and provided evidence that export-oriented industrial technologies serve as a driver of regional economic growth.

1. The research identified three approaches to understanding the essence of the "driver of economic growth". The authors substantiated the "activating", "integrating", and "institutional" approaches that methodologically reveal the fundamental features of the basic concept.

2. The "integrating" approach used to address the second task of the study attracted the most interest. The authors revised the definition of the "driver of economic growth" and proposed its classification with the following basic criteria: sphere of origin; source; method of origin; genesis and level of economic growth. The priority types of drivers examined in this study were identified.

3. The article presented the framework for the sectoral, market-related, innovative, and social impulses for economic growth generated by the export-oriented industrial technologies. Such generation features the creation of the chains of GRP growth impulses, both primary and secondary (derivative).

4. The paper assessed the primary impulses for economic growth generated by the exportoriented industrial technologies of the subjects of the Russian Federation. The authors performed the analysis of strengths of their relationships and excluded the dependence of change in the living standards on the development of industrial exports $(\mathrm{R} 2=0.2139)$ from the scope of the study. It is important to note that an innovative impulse generated by industrial technologies has no significant impact on the volume of GRP. This indicates that the Russian industrial exports in 2011-2016 were not based on innovation. It follows that in the Russian context, export-oriented industrial technologies affect the growth of GRP through the rise in domestic production and tax revenues coming to regions' consolidated budgets.

\section{References}

Akhapkin N. Yu., Ivanova L. N. (2014). Istochniki ekonomicheskogo rosta v Rossii: vybor prioritetov [The sources of economic growth in Russia: The choice of priorities]. Vestnik Instituta ekonomiki Rossiyskoy akademii nauk = The Bulletin of the Institute of Economics of the Russian Academy of Sciences, no. 6, pp. 41-50. (in Russ.) 
Drucker P. (2012). Menedzhment. Vyzovy XXI veka [Management challenges for the 21st century]. Moscow: Mann, Ivanov i Ferber Publ.

Ivanova L. N., Terskaya G. A. (2015). Tochki rosta i drayvery rosta: k voprosu o soderzhanii ponyatiy [Spots growth and growth drivers: The question of the contents concepts]. Zhurnal sovremennykh institutsional'nykh issledovaniy = Journal of Institutional Studies, vol. 7, no. 2, pp. 120-132. (in Russ.)

Ivanter A. (2014). Kachestvennyy rost s oporoy na instituty [Qualitative growth resting on institutions]. Ekspert $=$ Expert, no. 21 (900). Available at: http://expert.ru/expert/2014/21/kachestvennyij-rosts-oporoj-na-institutyi/. (in Russ.)

Kostin K. B. (2017). Drayvery rosta mirovoy ekonomiki [The growth drivers for global economics]. Izvestiya Sankt-Peterburgskogo gosudarstvennogo ekonomicheskogo universiteta = Bulletin of the Saint Petersburg University of Economics, no. 6 (108), pp. 19-24. (in Russ.)

Makhortov S. S. (2017). Drivers of sustainable economic growth in Russia. Materialy V Mezhdunarodnoy nauchno-prakticheskoy konferentsii "Aktual'nye problemy razvitiya finansovogo sektora" [Proc. 5th Int. Sci.-Prac. Conf. "Topical issues of financial sector development”]. Tambov, pp. 349-357. (in Russ.)

Knight F. H. (2003). Risk, neopredelennost' i pribyl' [Risk, uncertainty, and profit]. Moscow: Delo Publ.

Orekhova E. A. (2008). Vliyanie kharakteristik i svoystv ekonomicheskogo prostranstva na razvitie territorii [Influence of characteristics and properties of economic space on the development of the territory]. Regional'naya ekonomika: teoriya i praktika = Regional Economics: Theory and Practice, no. 10 (67), pp. 19-23. (in Russ.)

Schumpeter J. A. (1982). Teoriya ekonomicheskogo razvitiya [The theory of economic development]. Moscow: Progress Publ.

Becker M. C. (2005). The concept of routines: Some clarifications. Cambridge Journal of Economics, vol. 29, no. 2, pp. 249-262.

David P. (1985). Clio and the economics of QWERTY. American Economic Review, vol. 75, no. 2, pp. 332-337.

Friedman J., Alonso W. (1975). Regional policy: Reading in theory and applications. Massachusetts: Massachussetts Institute of Technology .

Hodgson G. M., Knudsen T. (2004). The firm as an iterator: Firms as vehicles for habits and routines. Journal of Evolutionary Economics, vol. 14, no. 3, pp. 281-307.

Lasuen J.R. (1969). On growth poles. Urban Studies, vol. 6, issue 2, pp. 137-161. DOI: https://doi. org/10.1080/00420986920080231.

Myrdal G. (1955). The political element in the development of economic theory. Routledge and Kegan Paul.

Nelson R. R., Winter S. G. (1982). An evolutionary theory of economic change. Cambridge, MA: Harvard University Press.

Perroux F. (1955). Note sur la notion de poles croissance. Economic Appliquee, vol. 1 \& 2, pp. 307- 320.

Pottier P. (1963). Axes de communication et développement économique. Revue économique, vol. 14, no.1, pp. 58-132. DOI: https://doi.org/10.3406/reco.

Romer P. (1990). Endogenous technological change. Journal of Political Economy, vol. 98, no. 5, pp. $71-102$.

Solow R. (2000). Growth theory: An exposition (Radcliffe Lectures). Oxford University Press.

\section{Information about the authors}

Yuliya G. Myslyakova, Cand. Sc. (Econ.), Associate Prof. of Marketing \& International Management Dept., Ural State University of Economics, 62/45 8 Marta/Narodnoy Voli St., Ekaterinburg, 620144, Russia; Sr. Researcher, Institute of Economics (Ural branch of RAS), 29 Moskovskaya St., Ekaterinburg, 620014, Russia

Phone: +7 (343) 371-38-15, e-mail: jul_jul@inbox.ru

Elena A. Shamova, Cand. Sc. (Econ.), Sr. Researcher, Institute of Economics (Ural branch of RAS), 29 Moskovskaya St., Ekaterinburg, 620014, Russia

Phone: +7 (343) 371-38-15, e-mail: heleneo@mail.ru 
Ю. Г. Мыслякова Уральский государственный экономический университет, Институт экономики УрО РАН, г. Екатеринбург, Российская Федерация

Е. А. Шамова $\quad$ Институт экономики УрО РАН, г. Екатеринбург, Российская Федерация

\title{
Экспортоориентированные промышленные технологии - драйверы экономического роста региона
}

\begin{abstract}
Аннотащия. Статья посвящена актуальной проблеме поиска источников активизации экономического роста регионов, решение которой имеет первостепенное значение для выстраивания эффективной промышленной политики развития государства. Доказывается научная гипотеза о том, что в современных условиях хозяйствования экспортоориентированные промышленные технологии являются драйверами экономического роста региона. Методологическая база - совокупность теорий экономического роста и положения региональной экономики. На основе анализа «активизирующего», «интегрирующего» и «институционального» подходов к пониманию сущности понятия «драйвер экономического роста» авторы уточнили его и предложили классификацию, базовыми критериями которой стали: сфера, источник и технологии возникновения, а также происхождение и уровень обеспечиваемого экономического роста. В статье выделены приоритетные виды драйверов, возникающих в результате развития экспортной ориентации территории, влияние которых на экономический рост было проанализировано посредством построения эконометрической модели. Научным результатом работы является эмпирическое доказательство (основанное на анализе данных о субъектах РФ за 2011-2016 гг.) того, что промышленные технологии, ориентированные на экспорт, генерируют два наиболее влиятельных импульса экономического роста: рост объема отгрузки продукции и сбор налогов в консолидированный региональный бюджет. Установлено, что в рассматриваемый период российский промышленный экспорт не имел под собой инновационной основы. Практическая значимость исследования заключается в возможности применения полученных выводов при разработке стратегий социальноэкономического развития регионов РФ.
\end{abstract}

Ключевые слова: регион; экономический рост; драйвер экономического роста; экспорт; экспортоориентированные технологии.

Для ицитирования: Myslyakova Yu. G., Shamova E. A. Export-oriented industrial technologies as drivers of regional economic growth // Journal of New Economy. 2019. T. 20, № 2. C. 166179. DOI: $10.29141 / 2073-1019-2019-20-2-10$

Дата поступления: 21 января 2019 г.

\section{Источники}

Ахапкин Н. Ю., Иванова Л. Н. (2014). Источники экономического роста в России: выбор приоритетов // Вестник Института экономики Российской академии наук. № 6. С. 41-50.

Друкер П. (2012). Менеджмент. Вызовы XXI века. М.: Манн, Иванов и Фербер.

Иванова Л. Н., Терская Г. А. (2015). Точки роста и драйверы роста: к вопросу о содержании понятий // Журнал современных институциональных исследований. Т. 7, № 2. С. 120-132.

Ивантер А. (2014). Качественный рост с опорой на институты // Эксперт. № 21 (900). URL: http://expert.ru/expert/2014/21/kachestvennyij-rost-s-oporoj-na-institutyi/ 
Костин К. Б. (2017). Драйверы роста мировой экономики // Известия Санкт-Петербургского государственного экономического университета. № 6 (108). С. 19-24.

Махортов С. С. (2017). Драйверы устойчивого экономического роста в России // Актуальные проблемы развития финансового сектора: материалы V Международной научно-практической конференции 22 ноября. Тамбов. С. 349-357.

Найт Ф. Х. (2003). Риск, неопределенность и прибыль. М.: Дело.

Орехова Е. А. (2008). Влияние характеристик и свойств экономического пространства на развитие территории // Региональная экономика: теория и практика. № 10 (67). С. 19-23.

Шумпетер Й. А. (1982). Теория экономического развития. М.: Прогресс.

Becker M. C. (2005). The concept of routines: Some clarifications. Cambridge Journal of Economics, vol. 29, no. 2, pp. 249-262.

David P. (1985). Clio and the economics of QWERTY. American Economic Review, vol. 75, no. 2, pp. 332-337.

Friedman J., Alonso W. (1975). Regional policy: Reading in theory and applications. Massachusetts: Massachussetts Institute of Technology .

Hodgson G. M., Knudsen T. (2004). The firm as an iterator: Firms as vehicles for habits and routines. Journal of Evolutionary Economics, vol. 14, no. 3, pp. 281-307.

Lasuen J.R. (1969). On growth poles. Urban Studies, vol. 6, issue 2, pp. 137-161. DOI: https://doi. org/10.1080/00420986920080231.

Myrdal G. (1955). The political element in the development of economic theory. Routledge and Kegan Paul.

Nelson R. R., Winter S. G. (1982). An evolutionary theory of economic change. Cambridge, MA: Harvard University Press.

Perroux F. (1955). Note sur la notion de poles croissance. Economic Appliquee, vol. 1 \& 2, pp. 307- 320.

Pottier P. (1963). Axes de communication et développement économique. Revue économique, vol. 14, no.1, pp. 58-132. DOI: https://doi.org/10.3406/reco.

Romer P. (1990). Endogenous technological change. Journal of Political Economy, vol. 98, no. 5, pp. $71-102$.

Solow R. (2000). Growth theory: An exposition (Radcliffe Lectures). Oxford University Press.

\section{Информация об авторах}

Мыслякова Юлия Геннадьевна, кандидат экономических наук, доцент кафедры маркетинга и международного менеджмента Уральского государственного экономического университета, 620144, РФ, г. Екатеринбург, ул. 8 Марта/Народной Воли, 62/45; старший научный сотрудник, Институт экономики УрО РАН, 620014, РФ, г. Екатеринбург, ул. Московская, 29 Контактный телефон: +7 (343) 371-38-15, e-mail: jul_jul@inbox.ru

Шамова Елена Алексеевна, кандидат экономических наук, старший научный сотрудник Института экономики УрО РАН, 620014, РФ, г. Екатеринбург, ул. Московская, 29

Контактный телефон: +7 (343) 371-38-15, e-mail: heleneo@mail.ru

(C) Мыслякова Ю. Г., Шамова Е. А., 2019 